\title{
Social work and society: Political and ideological perspectives
}

\author{
Sarah Pollock, Kate Parkinson, lan Cummins (Eds). \\ Policy Press, Bristol, 2020 \\ ISBN 978-1-4473-4470-4, pp.262, paperback, NZD35.40
}

$\mathrm{T}$ he book makes a compelling case that social workers, and the profession, need to be aware of the political and ideological context in which social work is practised. The book presents a clear overview of key political ideologies and explains how different areas of practice have been shaped by these. It also provides a useful guide to how social workers can understand, practise, and work for change within the current political context.

While each chapter is written by different authors, the text is congruent and structured in a clear and engaging manner. The book carefully and deliberately engages the reader, building up familiarity with key ideological and political concepts, and then showing how these have shaped the context in which social work is practised. The book is highly recommended to practitioners, students, and a wider audience.

The book begins with five chapters that introduce key political and ideological frameworks. The chosen ideologies are Socialism, Liberalism, Conservativism, Neoliberalism, and Feminism. Each chapter briefly discusses the history of each ideology, their core features, and how the ideologies have influenced social work practice. Throughout each chapter, links are made to the current social and political context. Though necessarily general, these introductions are clear and provide a useful place from which to approach the rest of the book.

The second section of the book considers a range of social and political contexts in which social work is practised, for example, within the criminal justice system. These chapters show how policy, and practice, sit within a social and political context. Each chapter describes key developments in each area, and how political reforms have amplified social issues. The book focuses on the political context in the UK with austerity and neoliberal reforms featuring heavily. The global nature of neoliberal capitalism means much of this discussion of political context is relevant to readers in other countries.

The third section of the book looks at the social issues with which social work has grappled in recent years. These include insecurity, migration and asylum, and radicalisation.

One of the features of this text which makes it particularly useful is its combination of theory and practice. Case studies and practical examples are used to illustrate key issues and the kinds of dilemmas that social workers face in practice. Each chapter finishes with critical questions for the reader to contemplate as well as recommended readings in order to further develop one's understanding of an issue.

The chapters which focus on social issues clearly illustrate how political reforms have harmed, or in some cases, benefited, those that we work with. These chapters also show how dominant social constructions change over time and discuss the implications of each of these. For example, the history and construction of mental health are presented alongside the need for collective change. Suggestions for how 
social workers can critically approach this area, and become involved in efforts to create change, are presented in a clear and useful manner. As a useful and practical introduction to social issues it is hard to fault the text.

As a political text, there are limitations in its approach. For example, the chapter on the criminal justice system describes how politicians have cynically promoted a punitive approach in order to bolster support. The chapter also describes the racist nature of the justice system, how prison labour is exploited, and how failures in this system make rehabilitation difficult. The chapter promotes a more humane approach to the justice system which prioritises rehabilitation and which reduces incarceration rates. While the chapter promotes the need for humanistic reforms, it seems to take the current criminal justice system for granted, including imprisonment, and advocates for a more active social work role within this system. The chapter does not explicitly consider the role of the criminal justice system within capitalism or engage with the possibility of prison abolitionism. It explicitly states that "there is a need for social work in the institutions of prisons" (pp. 142-143) and does not consider how social work perpetuates and upholds an inherently oppressive system. This is a recurring issue within the book. While the social and political context of issues is presented, the authors seem to take many components of the nation-state, and capitalist system, for granted.

The focus on pragmatic reforms, within the context of capitalism, may be a result of the introductory nature of the text, limitations in size, and current political conditions. As the text explicitly discusses, austerity and neoliberal capitalism have thoroughly stripped the welfare state and undermined relational social work. In this context, engaging in relational practice, and ensuring that society provides basic supports for those in need, requires radical action on the part of social workers and the profession as whole (which authors also discuss). While this is the case, it still important that students and practitioners understand the inherent limitations of reforms within the structure of capitalism. Failure to do so limits our intellectual and political development.

It is also worth noting that the book presents ideology as a system of political beliefs, or a lens through which our understanding of the world is constructed. While there is merit to this perspective, and it is useful in illustrating how political beliefs shape our understanding of the world, there are some limitations to this approach. The focus on ideology as a set of political beliefs minimises the degree to which ideology is also a material force that structures our understanding of the world, including our ability to make political choices. The pragmatic focus of the book, and the emphasis on critical reflection, also risk promoting a neoliberal conceptualisation of individuality.

These points should not be understood as a recommendation not to read or purchase the book. It would be unfair to judge the book for something which it does not aim to do. The book is stimulating and thought provoking; the authors clearly intended it to be approachable and applicable and I believe they achieved both.

While several authors within the book discussed the relationship between racism, ideology, and political discourses, the lack of a dedicated chapter on colonisation and white supremacy is unfortunate. Within the context of a colonised state (such as New Zealand), political ideology, and practice must always be considered through the lens of colonisation. Devoting a chapter to these issues, as is done with feminism, could have helped solidify an understanding of how western political and economic systems are inseparable from white supremacy. The book explicitly recognises that a specific chapter on this topic, as well as chapters on other topics, would have been useful. 
This book would be highly suitable for undergraduate students or postgraduate students who are looking for a general text. The clear links to practice, and discussion of the link between political context and practice also make this a valuable book for practising social workers.

Reviewed by John Darroch, University of Auckland 